\title{
Nasal Endotracheal Tube
}

National Cancer Institute

\section{Source}

National Cancer Institute. Nasal Endotracheal Tube. NCI Thesaurus. Code C122595.

A hollow tube that is directed into the trachea from the nose. 